\title{
POSSÊIDON E A REPRESENTAÇÃO DO MAR EM A ILÍADA, DE HOMERO
}

\section{POSEIDON AND THE REPRESENTATION OF THE SEA IN HOMER'S ILIAD}

\section{Martinho Guilherme Fonseca Soares ${ }^{1}$}

Resumo: A condição geográfica da Grécia fez com que o mar adquirisse papel preponderante na vida de suas sociedades. Em A Ilíada, Homero a ele se refere recorrendo a epítetos sonoros e coloridos os que se associam à figura de Possêidon, já cultuado, à época da escrita do poema, como deus dos domínios marinhos. A referência frequente do poeta à presença de um elemento úmido, caracterizado pelo emprego de tais epítetos, nos leva a analisar seu uso na epopeia para, em seguida, avaliarmos o porquê de seu emprego, sua relação com o deus e as atividades econômicas do Período Arcaico. Ao exploramos essas atividades, destacamos as paisagens naturais existentes no poema, que atuam na constituição de um modo próprio de os gregos antigos se relacionarem com o Mediterrâneo e, por conseguinte, com as manifestações do sagrado nele contidas.

Palavras-chave: Grécia Arcaica. Ilíada. Possêidon. Paisagens marinhas. Identidade.

Abstract: The geographic condition of Greece led to sea obtained a role of preponderant on its societies' life. In The Iliad, Homer refers to himself recurring to voiced and colorful epithets, which can be associated with Poseidon's figure, who has been revered, in that époque of poem writing, such as god of sea domains. The constantly poet's reference to the presence of an humid element, characterized by usage of these epi-

\footnotetext{
${ }^{1}$ Graduando em Licenciatura e Bacharelado em História pela Universidade Federal do Espírito Santo (Ufes), membro do Laboratório de Estudos Sobre o Império Romano, Seção Espírito Santo (Leir/ES). Atua junto ao Programa Institucional de Iniciação Científica da Ufes (PIC/Ufes/CNPq), sob orientação do Professor Dr. Gilvan Ventura da Silva. Contato martinhoesoares@hotmail.com
} 
thets, led us to analyze its usage in the epic to, following, evaluate why of its usage, relating to god and his economic activities from Archaic Period. Exploring these activities, we highlight the natural landscapes present in the poem, which performs in the constitution in a way of ancient Greeks relate to each other with the Mediterranean and, consequently, with the sacred manifestations of sacred and what has been contained in it.

Keywords: Greece Archaic. Iliad. Poseidon. Marine landscapes. Identity.

\section{Introdução}

Estudiosos dos mais diversos campos do conhecimento falam de uma poesia homérica que se originou nas sociedades gregas do Período Arcaico, ${ }^{2}$ como resultado de um processo oral de composição transmitida ao longo de gerações por aedos, ${ }^{3}$ poetas que ao incorporarem em seus versos cantados, aspectos da vida cotidiana, nos revelam o que poderíamos como modus operandi dessas sociedades. Tais narrativas, contidas em fontes tradicionalmente vistas como literárias, a exemplo de A Ilíada e a Odisseia transmitem visões de mundo do homem grego, verificamos uma relação profícua entre História e Literatura, que nos permite pensar o lugar das práticas sociais que, no caso grego, estão intimamente relacionadas ao sagrado, criando naquele contexto, uma sociedade particular, "os gregos de Homero", como foram citados por Walter Otto, estudioso alemão apaixonado pela poesia homérica, que dedicou a pesquisar os elementos filológicos das narrativas míticas.

\footnotetext{
${ }^{2}$ VIII e VI séculos a.C.

${ }^{3} \mathrm{O}$ termo corresponde a uma transliteração da palavra grega aoidos, que significa cantor.
} 
Ao narrar os saberes e os fazeres do homem arcaico, Homero recorre ao

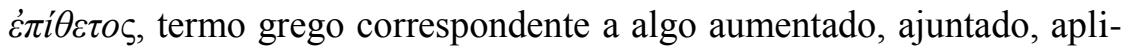
cado a um determinado nome com objetivo de qualificá-lo, características próprias da poesia. São as condições de produção da narrativa que nos interessam e por isso mesmo, exigem de nós algumas considerações primeiras sobre a epopeia como gênero literário inaugurado por Homero. Suas composições trazem versos carregados de epítetos, reveladores de uma relação semântica que se estabelece com o nome, chegando a exauri-lo e revelando-se portadores de uma lógica, um sentido próprio. Essa relação torna possível identificarmos determinado espaço, sujeito e paisagem, pelo adjetivo a ele atribuído. Esse recurso do poeta torna possível em A Ilíada e Odisseia, a percepção de uma visão de mundo clara e coerente, na qual o cosmo aparece perfeitamente ordenado. Tendo sua origem no que era comumente cantado, tais poemas abordam o que era importante no cotidiano das comunidades gregas arcaicas. É no seio desses mesmos agrupamentos que o divino manifestava-se em todos os aspectos da vida social. Ele era "[...] o fundamento de todo o ser e acontecer, e transparece com tanta clareza em todas as coisas e sucessos que cumpre evocá-lo mesmo a propósito do mais natural e do mais habitual. Nenhuma imagem do vivente é completa sem o divino" (OTTO, 2005, p. 11).

Na Ilíada, Homero aborda a Guerra de Tróia, de forma mais específica a cólera de Aquiles, o melhor dentre os guerreiros gregos. Todavia, os deuses decidem o conflito, eles participam e interagem no mundo dos vivos. São nas entrelinhas do poema que percebemos os 
homens, os animais, o céu, o mar e a terra, mas também o ser e agir das potestades no dia a dia. Essas "impressões do mundo grego" se processam na medida em que o poeta assume uma disposição própria para olhar o mundo que o cerca, "[...] trata-se de um olhar que não evita o detalhe, o insignificante, o banal, e que, ao mesmo tempo, não pode deixar de se deter no excessivo, no transcendente, no extraordinário" (SKLIAR, 2014, p. 43). O mundo dos deuses e o mundo dos homens são, em essência, um só. Nesse último, prevalecem relações que reforçam a necessidade da crença no divino e do rito por excelência em todas as atividades necessárias à subsistência dos homens. Ao ler Homero, nos damos conta da existência de uma devoção, uma relação de subserviência dos mortais diante dos imortais. Com efeito, no comércio e nas trocas, tão essenciais aos gregos, “[...] os homens dependem principalmente da boa vontade dos deuses, cujas boas graças tentam obter ou procuram apaziguar por meio de sacrifícios" (LEFÈVRE, 2013, p. 96). Assim posto, os deuses em tudo estão presentes e, como consequência, tornam toda paisagem sagrada e, a saber, digna de devoção.

Nesse cenário, recordando o século VIII a. C., o qual abrigou em seu decurso o desenvolvimento de uma intensa atividade econômica, ocorreu o estreitamento de relações entre a Grécia Balcânica, a Grécia oriental e o Ocidente do Mediterrâneo. Dessas relações surgiram os primeiros contatos, os assentamentos, os estranhamentos. O que disso resultou e suas transformações são questionamentos que ultrapassam os objetivos deste texto, no qual nos propomos a entender como os fatores econômicos e geográficos interagiram com o sagrado, como conforma- 
ram a paisagem grega no continente e no ultramar, fazendo com que Homero se apropriasse do espaço marinho ao longo dos 24 cantos de $A$ Ilíada. Trata-se de uma observação peculiar, pois:

Essa disposição da escuta e do olhar do poeta é inédita a cada vez que acontece. Um evento, um tempo, uma coisa, não podem ser incorporados, mas podem ser, sim, escutados... Na quietude, e na pausa... E podem também ser olhados... Com abertura, franqueza. Esse é o caráter perceptivo do poeta [...] (SKLIAR, 2014, p. 43).

O poema nos transmite uma visão de mundo que abrigava a interação homem e sagrado e de ambos com o ambiente natural ou viceversa. Haja vista que "o meio ambiente natural e a visão de mundo estão estreitamente ligadas: a visão de mundo, se não é derivada de uma cultura estranha, necessariamente é construída dos elementos conspícuos do ambiente social e físico de um povo" (TUAN, 2012, p. 116). Assim, nos é possível enfocar como se processaram as relações entre o divino e a vida cotidiana no contexto do Mediterrâneo grego no Período Arcaico. Esse procedimento torna-se possível porque Homero ao destacar na epopeia por meio do epíteto, o olhar e o sentimento despertado pelas paisagens naturais, nos aproxima mais do homem grego.

\section{O emprego do epíteto em $\boldsymbol{A}$ Ilíada}

As obras homéricas, tal como designamos o conjunto de cantos contidos em A Ilíada e Odisseia, como assinalado, tem sido alvo dos mais variados estudos ao longo do tempo. No campo da teoria literária, a crítica reside na estrutura do texto, que não é nossa abordagem. Dos textos citados, nos interessa o que a poesia conta sobre a memória cole- 
tiva do homem grego e sua vida cotidiana. Para Vidal-Naquet (2002, p. 110), "o verdadeiro assunto de Homero é a terra dos homens e, acima dela, o mundo dos deuses". Um cotidiano que permaneceu por muito tempo obscuro. Nas sociedades gregas, “[...] não existe uma casta de sacerdotes com uma tradição fixa, não há nem Veda, nem textos da Pirâmide. Tão pouco existe uma revelação vinculadora na forma de livros sagrados" (BURKERT, 1993, p. 243). As obras de Homero, nesse contexto, representaram uma "revolução" no século VIII a.C., pois permitiram "[...] uma guinada fundamental para o historiador da Grécia: pela primeira vez, ele dispõe de documentos escritos que ultrapassam o estágio das peças contábeis e oferecem uma visão global das mais variadas áreas, como a sociedade, a política, as crenças, as trocas (LEFÈVRE, 2013, p. 87). Ao estudarmos o Mediterrâneo no contexto geográfico grego, temos por objetivo apontar o desenvolvimento de algumas dessas áreas.

A Ilíada e Odisseia constituem as mais antigas obras de que temos notícia no Ocidente e são, tal como sugere Jacques Le Goff, ${ }^{4}$ um monumentum, ou seja, sinais do passado. No caso da primeira, nossa fonte de estudo, homens e deuses, assim como, a paisagem natural, aparecem adornados de epítetos que segundo Milman Parry, ${ }^{5}$ ao publicar em 1928 sua tese "L'Épithète Traditionnelle dans Homère : Essai sur un problème de style Homérique", reunidos na condição de grupo de pala-

\footnotetext{
4 Consultar o verbete "Documento/Monumento" da obra História e Memória. ${ }^{5}$ Estudioso Norte Americano da poesia épica, considerado percussor nos estudos do gênero.
} 
vras, traduzem-se como um procedimento padronizado pelo poeta, de modo a facilitar a composição da obra. A Ilíada teria sido o primeiro dentre os dois poemas atribuídos a Homero. Ao longo de seus 24 cantos, o espaço marítimo aparece descrito por meio de epítetos variados e em diferentes situações. Destacamos alguns deles, aos quais retornaremos mais tarde: mar de políssonas praias; mar de políssonas ondas; mar salino-cinza; mar profundossoante; oceano cor-de-vinho afutos; mar cor de vinho; mar vinho-escuro; mar picoso; mar polissono; mares enevoados; mar undoso-fluente; mar salino-santo; mar salino-sacro. As formas apresentadas pelo poeta pouco variam e sua estrutura gramatical. Analisadas no conjunto da obra tendem a indicar as sensações despertadas pelas paisagens marinhas. As designações acima são inúmeras vezes empregadas, fazendo com que tais repetições fossem encaradas, por Parry (1980, p.14), como sinal de que o poeta lançou mão, quando da composição, de um formulário básico, uma fórmula “[...] expressão que é regularmente empregada nas mesmas condições métricas, para exprimir uma certa ideia essencial". Reunimos no quadro abaixo o conjunto dessas expressões, que nos permite analisa-las de modo mais sistemático, articulando um complexo categorial primário passível de sofrer reformulação. ${ }^{6}$

Quadro 1: paisagens marinhas representadas no Canto I

Canto/verso

Personagem (s)
envolvida (s)

\footnotetext{
${ }^{6}$ Dada à extensão da fonte, o canto I foi escolhido com base nos variados epítetos que reúne, a partir dos quais nos é permitido pensar as adjetivações feitas por Homero ao referir-se ao mar.
}

Sensações manifestadas 


\begin{tabular}{|c|c|c|c|}
\hline I/34 & $\begin{array}{c}\text { Crises, o sacer- } \\
\text { dote; Criseida, a } \\
\text { filha raptada e } \\
\text { Agamêmnon }\end{array}$ & $\begin{array}{c}{[\ldots] \text { ao longo do mar }} \\
\text { de políssonas praias } \\
{[\ldots]}\end{array}$ & Medo \\
\hline $\mathrm{I} / 157$ & $\begin{array}{c}\text { Agamêmnon, } \\
\text { Ájax, Idomeneu } \\
\text { e Odisseu }\end{array}$ & {$[\ldots]$ Mar salino [...] } & Apreensão \\
\hline $\mathrm{I} / 157$ & Aquiles & $\begin{array}{c}\text { Muitos montes me- } \\
\text { deiam sombreados } \\
\text { entre nós, e o mar } \\
\text { sempre-sonante }\end{array}$ & Medo \\
\hline $\mathrm{I} / 327$ & Agamêmnon e & $\begin{array}{c}{[. .] \text { e ambos vão }} \\
\text { Aonstrangidos, junto } \\
\text { ao mar insone }\end{array}$ & Vingança/cólera \\
\hline $\mathrm{I} / 437$ & Crisa e Odisseu & $\begin{array}{c}{[\ldots] \text { na areia do mar }} \\
\text { rebenta }\end{array}$ & Cólera \\
\hline $\mathrm{I} / 482$ & & $\begin{array}{c}{[. . .] \text { as ondas - rastro }} \\
\text { púrpura - soando, } \\
\text { soando [...] }\end{array}$ & Sorte \\
\hline
\end{tabular}

As formas empregadas são, a princípio, o modo como os gregos experienciavam o mar na condição de lugar de residência/manifestação do sagrado, evidenciado pelas expressões "mar salino-santo" e "mar salino-sacro". Os termos designam experiências na medida em que "[...] a interpretação simbólica e a atribuição do sagrado aos lugares e às paisagens são duas maneiras características e estreitamente relacionadas de responder ao mundo" (TUAN, 2012, p. 199). Os epítetos são símbolos e, “[...] um símbolo é um repositório de significados. Estes emergem das experiências mais profundas que se acumulam através do tempo. As experiências profundas têm, muitas vezes, um caráter sagrado, extraterreno, mesmo quando elas se originam na biologia humana" (TUAN, 2012, p. 203). Nesse sentido, os gregos que observamos na Ilíada fazem 
do topos um lugar de expressão de seus sentimentos. Essa condição da natureza experimentada pelos homens exige que analisemos a religião grega como veremos a seguir.

\section{$O$ culto grego arcaico}

A presença do divino no mundo grego é desde o princípio retratada por Homero tanto em A Ilíada como na Odisseia, dirigindo-se no início dos dois poemas, a uma divindade. Assim, a Grécia descrita por Homero abrigou em seu decurso, homens e deuses que se relacionavam mutuamente, criando condições nas quais "[...] tudo se reduz a uma narração a dois níveis, como que num palco duplo: ação divina e ação humana influenciam-se reciprocamente. Os deuses são espectadores, mas intervêm rapidamente quando se sentem afetados" (BURKERT, 1993, p. 247). Neste mundo profundamente marcado pela presença do sagrado é que "[...] a unidade espiritual dos gregos foi criada e preservada pela poesia que, vindo ainda do domínio da oralidade, reuniu de modo feliz a liberdade e a forma, a espontaneidade e a configuração [...]” (BURKERT, 1993, p. 245). No plano dessa intervenção das deidades na vida cotidiana dos gregos, A Ilíada, destaca figuras como Zeus, Hera, Atena, Possêidon, ${ }^{7}$ Ares, Afrodite, Hefesto e Apolo, dentre outras. Zeus por exemplo, o "ajunta nuvens", tal como designado por Homero, parece ter sido cultuado amplamente desde o Período Micênico

\footnotetext{
${ }^{7}$ Optamos por adotar tal configuração ao nome do deus por ser a mais encontrada nas traduções para o Português, todavia, em alguns momentos, variações podem aparecer em razão das diferenças semânticas de uma língua para outra.
} 
(1600-1200 a. C) conforme indicam placas de Linear B encontradas nos palácios de Cnossos e Pilos. Para Burkert (1993, p. 255) “[...] na época micênica Zeus é um dos deuses mais importantes, talvez o deus supremo: um dos meses tem o seu nome".

Zeus é o rei dos deuses, $\beta \alpha \sigma l \lambda \varepsilon v ́ \varsigma$, conforme designou Homero e, a exemplo das demais divindades, também se posicionou a favor de gregos e troianos, ${ }^{8}$ por vezes se apiedando de uns e de outros. No decurso da guerra, as divindades intervinham cada qual à sua maneira para garantir a vitória daqueles de que se apiedavam. Possêidon, o "treme terra", manifestamente intervém a favor dos aqueus. O "treme terra", a exemplo de Zeus, também era cultuado de forma bastante difundida desde o Período Micênico. As mesmas placas em Linear B, encontradas em Cnossos e Pilos, indicam a presença do deus na vida religiosa dos micênicos. Sua participação nas atividades corriqueiras dos gregos rendeu-lhe no século VIII a.C., uma cidade em sua honra, na Itália meridional, a que chamaram Posidônia, "a cidade de Possêidon". Da mesma forma, Homero deu ao deus lugar de destaque em sua Ilíada, seja pelo emprego de epítetos a ele atribuídos, seja pela recorrente referência aos elementos com os quais o deus se relaciona. Elementos que transmitem a ideia de uma devoção consolidada quando da composição do poema, que teria ocorrido por volta de 700 a.C.

${ }^{8}$ Zeus varia sua posição ao longo dos cantos. Não se trata de estar neutro, como afirmam alguns autores. A depender daqueles que a ele se dirigem, muda de posição, beneficiando em alguns momentos gregos e, em outros, troianos. 
As potestades gregas possuíam atributos por meios dos quais interferiam na vida dos homens. De fato, "o mundo de Homero ordenava-se por uma distribuição dos domínios e funções entre grandes deuses: a Zeus cabe a luz brilhante do céu (aither); e a Hades, a sombra brumosa (aer); a Posidão, o elemento líquido" (VERNANT, 2014, p. 113). Na Ilíada, ao aparecerem, os deuses estão, via de regra, associados a determinados lugares que segundo Mircea Eliade (2001, p. 18), podem revelar a existência desses espaços que assumem a condição de hierofania, de manifestação do sagrado. Assim "[...] para aqueles que têm uma experiência religiosa, toda Natureza é suscetível de revelar-se como sacralidade cósmica”. É esse o caso grego, em que os deuses recorrem a um conjunto de práticas e sinais que indicam sua manifestação em determinados lugares e paisagens. Atenção especial parece ser dada pelo poeta a Possêidon, contudo há que se considerar que "o mundo homérico conhece um grande número de figuras divinas, mas a importância delas é muito variada. Poucas são as que se imaginam presentes nos sucessos decisivos da vida e recebem culto" (OTTO, 2005, p. 121). Possêidon, certamente, figurou entre essas divindades, haja vista evidências de seu culto encontradas por toda a Grécia Continental e também pela Magna Grécia.

O deus teve um passado associado aos cavalos, razão pela qual tem referência à existência de um "Possêidon equino" que, nos tempos de Homero, passa a ser cultuado como um deus do mar, mas sua ligação com cavalos, “[...] também está ligada à água. Existe a nascente do cavalo, Híppou Créne, aberta pelo casco do primeiro cavalo" (BURKERT, 
1993, p. 277). A relação do deus com a terra também é enfatizada, pois um substantivo composto, afirma Burkert, apresenta "o vocativo - potei - senhor, porém a segunda componente - $d a$ - permanece desoladoramente ambígua" (BURKERT, 1993, p. 273). Já para Otto, não há dúvida que o segundo componente do nome do deus está relacionado com à terra, fato que, para ele, confirma-se a partir da identificação dada por Homero ao deus como "o treme terra". Assim, ao sacudir as montanhas, “[...] Possêidon não apenas a fende como faz surgirem dela águas salobras e doces, e por isso é o deus das fontes e rios. Mas sua majestade se manifesta plenamente no mar, cuja agitação semelha o terremoto" (OTTO, 2005, p. 23).

Embora Possêidon tenha sido associado como senhor dos mares em um segundo momento, assim o trataremos, pois é nessa condição que foi cultuado, pelo menos desde os gregos de Homero. Mas a relação dos povos gregos com o mar pode ser mais antiga, haja vista que desde o final da Idade do Bronze (3500-2100/2000) os povos fenícios passam a frequentar as ilhas e o continente gregos.

\section{Homero e a construção de uma geografia grega}

Uma primeira consideração é necessária ao falarmos de uma geografia da Grécia: o espaço físico não é algo que se encerra em si mesmo, ele está associado de forma contínua ao mundo sobrenatural. $\mathrm{O}$ homem grego é profundamente religioso, de maneira que a paisagem o permite identificar-se como pertencente a um mundo posto sob a proteção dos deuses, ou seja, marcado pelo sagrado. Sob essa ótica, e na 
perspectiva de Alfonso Maria Di Nola, entende-se que "um lugar é santo, separado, agnos, quando é habitado ou tocado por uma forma sobrenatural que determina um sentimento de medo-respeito" (DI NOLA, 1987, p. 123).

Nesse contexto, a proximidade com o mar (grego), conforme eles mesmos designavam o Mediterrâneo, propiciou o estabelecimento de relações de troca e comércio que naturalmente envolveram a navegação. A Grécia Arcaica, como mencionado por ocasião de nossa referência à fundação de Posidônia, no Sul da Itália, abrigou entre os séculos VIII e VI a.C., um processo de colonização do território que viria a se tornar a Magna Grécia. Tal processo teve desde sempre o mar como referência, seja devido o fornecimento de víveres, ou como via de navegação para os gregos imigrantes, que buscavam se apoderar de novas terras e fortalecer os laços comerciais.

Na Ilíada, o mar, via fluvial para novas terras, é retratado como imponente e revolto, o que exigia daqueles que nele se aventuravam uma invocação a Possêidon para que trouxesse bons ventos e conduzisse bem a ida e o retorno. Esse atributo do deus pode ser observado no Canto VII de A Ilíada, no que os troianos são favorecidos no combate, “[...] assim como um deus aos navegantes ansiosos favorece com um vento amigo, quando já esmoreceu de sulcar o oceano movendo a pulso os remos lisos, aos ansiosos Tróicos os dois irmãos apareceram" (Il., VII, v. 4-8). Para além de uma fonte de alimentos, o mar é também uma superfície de deslocamento e assim "o navio, a rota marinha, o porto há muito equipado, a cidade comercial, são instrumentos a serviço das ci- 
dades importantes, dos Estados e das economias mediterrânicas, os instrumentos de seus intercâmbios e, consequentemente, de sua riqueza" (BRAUDEL, 1988, p. 36). Trata-se do desenvolvimento de uma Talassocracia, ${ }^{9}$ que implicou num verdadeiro "culto ao mar", já que as condições climáticas da Grécia ofereciam "uma bela temporada de navegação, de abril/maio até setembro/outubro" (LEFÈVRE, 2013, p. 37). Este culto, segundo Rodríguez López, se dava em circunstâncias que transcrevemos abaixo:

Prece e sacrifício foram os dois atos essenciais da conduta religiosa grega. Homens que adoravam Poseidon, como seu protetor, elevavam a ele suas preces antes de empreenderem uma viagem, em termos simples e sinceros, como evidenciado pelas inscrições que chegaram a nós como "dá-nos uma viagem segura." Sacrifícios também eram oferecidos em sua honra cada vez que se chegava de uma viagem perigosa (RODRÍGUEZ LÓPEZ, 2002, p. 36)

O movimento expansionista grego buscou por meio do estabelecimento de suas apoikai, ${ }^{10}$ assentar-se em locais favoráveis à fundação de portos, facilitando o carregamento das embarcações que à Grécia retornariam com suprimentos. Dessa forma, a colonização pode ser explicada, em grande parte, pela necessidade de as comunidades gregas viabilizarem seu abastecimento, recorrendo ao comércio e às trocas.

Walter Otto considera que “[...] não há no mundo homérico uma alternativa entre autonomia humana, de um lado, e a influência ou pro-

\footnotetext{
${ }^{9}$ Designa as sociedades cuja base econômica está centrada nos domínios marítimos.

${ }^{10}$ Cidades fundadas no território estrangeiro.
} 
teção dispensada pela divindade, de outro. O que no homem quer e faz é ele mesmo e a divindade. Ambas as coisas são verdadeiras e no fundo, a mesma coisa" (OTTO, 2005, p. 166-167). Por conseguinte, tudo aquilo que se passa com os homens está sob a influência dos deuses, ideia que Homero deixa transparecer ao elevar o mar à condição de lugar marcado pelo divino, conforme podemos observar no Canto II em que, no contexto de um motim desencadeado pelos argivos, o poeta destaca que, estando os aqueus amedrontados diante da suntuosidade dos portões de Tróia “[...] uns exortando os outros a tomar os navios, arrastá-los ao mar salino-sacro, limpos canais [...]" (Il., II, v. 151-153), queriam retornar. Noutro trecho, Agamêmnon insufla os gregos à batalha: "então, obedeçam-me o mando: as naus postas primeiro a seco à beira-mar, façamos arrastar e lançar ao salino-mar divino [...]” (Il., XIV, v. 74-77).

A força dada a Possêidon nos versos da epopeia demonstra que as manifestações da natureza estavam intimamente relacionadas à sua vontade. Cercados pelo mar, tudo estava sob sua constante influência, de forma que catástrofes naturais também eram atribuídas ao deus marítimo. Sob esse olhar, Burkert explica o trecho da Odisséia em que a força do deus fica transparecida:

O mito descreve como Possêidon quebra as montanhas e lançaas ao mar com seu tridente. Assim, Ajax, o lócrida, que queria desafiar os deuses, é lançado para as profundezas juntamente com o rochedo onde se refugiava. Assim também, a ilha de Nisiro é arremessada sobre o gigante Polibotes. Dizia-se que tinha sido o seu tridente que tinha aberto o vale do Tempe, entre o Olimpo e Ossa, para que o lago que cobria a Tessália pudesse escorrer para o mar (BURKERT, 1993, p. 275) 
O surpreendente torna-se, assim, manifestação do sobrenatural. Disso decorre, por exemplo, a necessidade de adorar aos deuses para aplacar sua ira, ocasionando o surgimento de templos por toda a Grécia, dentre os quais, "[...] muito importante é o templo de Posseidon localizado no promontório do Cabo Súnion, na ponta sul da Ática, onde o mar é muitas vezes abalado pelas tempestades, através das quais o deus mostrava seu poder" (RODRÍGUEZ LÓPEZ, 2002, p. 40). Segundo Burkert, "[...] todos os barcos que se dirigiam para Atenas eram saudados ao longe pelo templo luminoso em honra de Possêidon, situado no cabo Súnion” (BURKERT, 1993, p. 274).

Segundo o relato de Pausânias, ${ }^{11}$ a própria Corinto traz, nos primórdios de sua fundação, uma relação com o mar. Sua descrição indica que os deuses Hélios e Poseidon teriam empreendido uma disputa pela região que resultou na tomada da parte alta da cidade (Acrocorinto) pelo primeiro e das demais regiões, incluindo a parte baixa, por Possêidon. Outro relato, este por sua vez, oriundo do poeta grego Eumelus, ${ }^{12}$ designa a região como pertencente à deusa Épira, filha do deus Oceano.

\footnotetext{
${ }^{11}$ Pausânias viveu no século I d. C, mas sua obra, aliás, a única de sua autoria que se tem notícia, remonta a uma Grécia Continental dos tempos arcaicos a qual percorreu e relatou em "Descrição da Grécia". A obra é considerada a primeira de caráter periegético ao descrever as formações geológicas e paisagens do território grego e também, o aspecto mítico que envolve a fundação de muitos desses locais, sendo basilar para os estudos de uma Geografia Grega ao lado de Hecateu de Mileto e Heródoto.

${ }^{12}$ Poeta grego do final dos séculos VII ou VI a.C., ao qual Pausânias recorre para escrever sobre Corinto.
} 
${ }^{13}$ Assim como Corinto, outras regiões integraram o movimento de expansão comercial, o que pode justificar a difusão do culto de Possêidon na Magna Grécia e Silícica.

\section{O Mediterrâneo e o mar em A Ilíada}

A Grécia dos tempos arcaicos insere-se num contexto espacial segundo o qual "[...] Homero acreditava que a Terra era redonda, plana e circundada por uma grande corrente" (TUAN, 2012, p. 63). Em sua paisagem predominantemente cercada por montanhas, o mar se transforma em estreitos. Esse é o caso do Mar Egeu, do Mar Negro, do Mar Tirreno e do Adriático. Geografia que permanece pouco alterada nos dias atuais. Na perspectiva trazida por Tuan:

"O mar, a terra fértil e as ilhas figuraram proeminentemente na imaginação dos gregos antigos. Isso não surpreende, pois os gregos dependiam do mar e dos pequenos espaços de solo fértil para sua subsistência; e as ilhas eram âncoras de segurança ou oásis de vida nas águas do oceano" (TUAN, 2012, p. 170).

Lefèvre considera que:

"Há outro elemento pelo menos tão presente quanto as montanhas na paisagem grega: o mar, sempre a menos de $100 \mathrm{~km}$ de qualquer ponto do território, sendo que, inversamente, quem navegava no Egeu nunca precisava percorrer mais de $60 \mathrm{~km}$ para chegar à terra, sempre ao alcance da vista (LEFÈVRE, 2013, p. 36).

${ }^{13}$ Oceano, na classificação feita por Hesíodo, é um deus da primeira geração dos deuses gregos, depois teriam viando os Titãs e em seguida os deuses do Olimpo. 
Tais condições tornaram possível a incorporação da pesca e das trocas no dia a dia das sociedades que habitavam a costa do Mediterrâneo, fazendo com que o deus do mar fosse considerado "[...] sobretudo, senhor e ajudante dos pescadores. Por isso, os pintores retratam-no com um peixe nas mãos, frequentemente com um delfim (BURKERT, 1993, p. 274). Importante considerar que especialistas têm se dedicado ao estudo do mar como entidade separada das demais paisagens. É o que propõe Ina Berg (2007), arqueóloga da Universidade de Manchester, ao empregar o termo seascapes, para designar as paisagens marinhas, entendidas como o meio natural/geográfico somado às sensações despertadas em cada indivíduo ao relacionar-se com o espaço marítimo. Essa é a relação que observamos em A Ilíada e que Yi-Fu Tuan classifica como "topofilia", termo que designa "[...] todos os laços afetivos dos seres humanos com o meio ambiente natural [...]" (TUAN, 2012, p. 135). Trata-se portanto, do sentimento associado ao lugar. Esse sentimento permeou o cotidiano dos marinheiros gregos que bem conheciam o Mediterrâneo e sabiam que ele era essencialmente, um mar de tempestades. Calmo no verão e revolto durante o inverno.

Para Otto (2005, p. 23) "“[...] Possêidon foi outrora um deus preeminente, de um domínio quase universal [...]", condição que o torna temido e, ao mesmo tempo, digno de devoção em toda a Grécia. Outro aspecto pode explicar a relação de medo/proteção dos gregos para com o mar. Ele era também lugar propício à pirataria, "que prospera nesse dédalo insular rico em angras e outros portos naturais que facilitam a navegação para todos mas constituem esconderijos para emboscadas e bases de 
largada para razias (LEFÈVRE, 2013, p. 46). O mar descrito por Homero, na condição de paisagem do medo, aterrorizava não só por suas tempestades, mas também, por ser gigantesco e fascinante. Quando se estava numa pequena embarcação indo de um lado para o outro a depender dos ventos, as distâncias eram maiores e maiores, também, as incertezas. Essa é a perspectiva de Braudel, segundo a qual "falar do Mediterrâneo na história, é portanto - primeiro cuidado e preocupação constante atribuir-lhe suas dimensões verdadeiras, imaginá-lo numa vestimenta desmesurada. Ele sozinho era, outrora, um universo, um planeta" (BRAUDEL, 1988, p. 31).

A relação dos gregos com o mar é, portanto, plural, na medida em que não deriva de um só fator, seja o econômico, o religioso ou o cultural, mas revela-se carregada de afetividade. Nesse sentido:

"Para compreender a preferência ambiental de uma pessoa, necessitaríamos examinar sua herança biológica, criação, educação, trabalho e os arredores físicos. No nível de atitudes e preferências do grupo, é necessário conhecer a história cultural e a experiência de um grupo no contexto de seu ambiente físico" (TUAN, 2012, p. 91).

Os epítetos que destacamos anteriormente, "mar cor de vinho" e "mar cinza", podem, no ambiente grego, representar uma relação que, para Tuan, significa que "a atitude em relação ao mar era ambivalente. O mar tinha beleza e utilidade, mas era também uma força escura e assustadora [...] quando calmo, aparecia com a beleza de um "vinho escuro", quando bravo, engolia navios e marinheiros" (TUAN, 2012, p. 171). O "mar cor de cinza," bravio, ao qual Homero se refere em seus 
poemas, é resultado dos fenômenos meteorológicos característicos da bacia do Mediterrâneo, que a partir de outubro vê suas depressões oceânicas carregadas de umidade:

"Os ventos de todas as direções avançam sobre elas e empurram-nas, rechaçam-nas em direção ao Oriente. O mar escurece, assume as tonalidades cinzas do Báltico, ou então, enterrado sob uma poeira de espuma branca, parece cobrir-se de neve. E desencadeiam-se as tempestades, as terriveis tempestades. Ventos devastadores: o mistral, o borah, atormentam o mar e, em terra, é preciso abrigar-se contra seu furor e sua violência" (BRAUDEL, 1988, p. 13)

A tempestade e o furor das águas que a acompanham são portadoras da seguinte característica: "[...] tudo o que é grande é perigoso pode causar dano ao homem que não está sob sua proteção. Nos domínios dos deuses mora o perigo. Muitas vezes eles irrompem como uma tempestade na bem ordenada vida dos homens" (OTTO, 2005, p. 220). Tais tempestades, classificadas por muitos autores como sendo devastadoras e, por sua vez, presentes no cotidiano das populações instaladas em torno do Mediterrâneo, fazem com que seu temor se estenda pelos séculos, de modo que Burkert as considerem "uma epifania do deus que no ano de 480 a.C., "[...] se levantou subitamente do Norte e se abateu sobre a frota persa na Tessália, os gregos fizeram votos a Possêidon, derramaram líquidos no mar e iniciaram um novo culto de Possêidon, o salvador, sóter [...]” (BURKERT, 1993, p. 274). Nesse sentido, “[...] o mar assusta, porque representa perigo, surpresa, riscos bruscos, mesmo nos caminhos familiares. As cerimônias religiosas que se mantiveram até nossos dias em tantos portos do Mediterrâneo são ritos mágicos in- 
cessantemente repetidos contra os caprichos das tormentas e tempestades" (BRAUDEL, 1988, p. 37).

O poder da tempestade de inverno transparece nos versos da epopeia quando, no Canto III, os exércitos de Páris e Menelau se põem frente a frente e assim constituem uma metáfora segundo a qual:

Dispostas as fileiras, sob a hegemonia do capitães de cada parte, já os Troianos investem, estridente alarido de pássaros; assim gritam os grous, sob o céu, à espantosa tempestade invernal fugindo sobre o Oceano irruente a morte e a Moira levando aos Pigmeus, pois do alto do ar lhes movem guerra lutulenta (Il., III, v. 1-7).

No Canto IV, o mar cinza é explorado como um espaço que deve ser ocupado com reserva. Diante das fileiras de homens, Idomeu, ${ }^{14}$ encorajava os que:

"[...] À ominosa guerra se furtavam, com palavras coléricas os verberava: 'flecheiros fanfarrões, Aqueus vexaminosos, não tendes brio? Por eu - como filhotes tímidos de corça que, depois de correr pelo prado, exânimes, detêm-se - estais inermes, pávidos, sem fibra para a luta? Esperais que os troianos avancem até onde nossas naus descansam, lindas popas, na praia, à beira do mar cinza? ou será que aguardais a mão de Zeus Croníade?" Il., IV, v. 239 - 247).

Ainda no mesmo Canto, o mar é lembrado como lugar de beleza e de contemplação. Ares castigava os gregos em batalha e Hera diante do exposto, toma seus cavalos que a conduzem num carro até a presença de Zeus a quem se dirige nos seguintes termos:

${ }^{14}$ Rei de Creta e também um guerreiro grego estimado por Agamêmnon. 
Zeus Pai, se eu castigar Ares com o rigor devido e o afastar do campo de batalha? Volta-se e lhe responde Zeus ajunta-nuvens: mais valerá que incites de encontro a ele Atena predadora; ninguém melhor para puni-lo. Disse. E assentiu a deusa braçosbrancos, Hera. Fustigou os corcéis que de bom grado voam entre a terra e o estelário. Quanto abarca a vista, a perder-se na bru$m a$, de quem, de um mirante contempla o oceano roxo, cor de vinho [...] (Il., IV, v. 262-271).

Associado à "cor de vinho", o mar desperta também ambição e glória. Em meio à batalha, Heitor ${ }^{15}$ propõe aos aqueus um duelo entre ele e o melhor dos guerreiros gregos e projeta sua vitória: "um dia, no futuro, em suas naus polirreme sulcando as ondas do mar cor-de-vinho, um navegante dirá: vejam, é a tumba de um herói de antanho, matou-o Héctor fulgurante. Dirá. E minha glória viverá perene” (Il., VII, v. 8691).

\section{Considerações finais}

Num contexto de interação dos gregos com o sagrado, Homero nos permite, por meio da poesia, pensar o lugar das práticas religiosas na organização do mundo. Ao considerarmos que "o espaço é um elemento da cognição humana e expressa princípios de ordem e classificação segundo as necessidades das ações sociais" (NAVARRO, 2007, p. 15), poesia, natureza, economia e cosmos são, no mundo de Homero uma só coisa. Assim, o espaço marinho representou para as sociedades gregas arcaicas uma paisagem capaz de unir tais elementos na medida em que, através das manifestações de Possêidon que nele ocorreram, os

${ }^{15}$ Príncipes de Troia e, dentre os troianos, o melhor dos guerreiros. 
demais aspectos da vida social se configuraram, tal como exemplificado por nossa referência ao desenvolvimento de atividades comercias no VIII século a.C., que em seu transcorrer, ora remetiam à força e ira do deus, ora às bem-aventuranças que também o acompanhavam. Nesse sentido, de cunho literário, A Ilíada nos permite historicizar os sujeitos nela contidos e suas respectivas visões de mundo.

\section{Referências}

\section{Documentação textual}

HOMERO. Ilíada. Tradução de Haroldo de Campos. São Paulo: Benvirá, 2010. v. I e II.

\section{Obras de apoio}

BERG, I. Aegean Bronze Age seascapes: a case study in maritime movement, contact and interaction. in: ANTONIADOU, Sophia; PACE, Anthony. (Eds.) Mediterranean Crossroads. Atenas Pierides Foundation, 2007.

BRAUDEL, F. O espaço e a história no Mediterrâneo. São Paulo: Martins Fontes, 1988.

BURKERT, W. Religião grega na época clássica e arcaica. Lisboa: Fundação Calouste Gunbenkian, 1993.

ELIADE, M. O sagrado e o profano: a essência das religiões. São Paulo: Martins Fontes, 2001.

FLORENZANO, M. B. B; HIRATA, E. F.V. Estudos sobre a cidade antiga. São Paulo: Edusp, 2009.

LE GOFF, J. História e memória. 5. ed. São Paulo: Unicamp, 2003.

LUNA, S.V.de. Planejamento de pesquisa: uma introdução. São Paulo: Educ, 2002. 
NAVARRO, A.G. Sobre el concepto de espacio. Revista do Museu de Arqueologia e Etnologia da Universidade de São Paulo. São Paulo, n.17, p. 3-21, 2007.

OTTO, W. F. Os deuses da Grécia: a imagem do divino na visão do espírito grego. São Paulo: Odysseus, 2005.

PARRY, M. The traditional epithet in Homer. In: Parry, Adam (Ed.). The making of Homeric verse. N. York: Oxford University Press, 1987.

RODRÍGUEZ LÓPEZ, M. I. Poseidon y el Thiasos marino em el arte mediterrâneo: desde sus origens hasta el S. XVI. Tese (Doutorado). Universidade Complutense de Madrid - Departamento de História del Arte II (Moderno), 2002.

SKLIAR, C. O ensinar enquanto travessia: linguagens, leituras, escritas e alteridades para uma poética da educação. Salvador: Edufba, 2014.

TUAN, Y. Topofilia: um estudo da percepção, atitudes e valores do meio ambiente. Londrina: Eduel, 2012.

VIDAL-NAQUET, P. O mundo de Homero. São Paulo: Companhia das Letras, 2002.

Recebido em: 07/04/2016 Aceito em: 17/08/2016 
